IRA-International Journal of Management \&

Social Sciences

ISSN 2455-2267; Vol.17, Issue 02 (Q.2 2021)

Pg. no. 46-55.

IRA Academico Research

\title{
Influence of Gender Diversity on Organization Performance at Kenya Urban Roads Authority
}

\author{
Wesang'ula Salome Nang'oni ${ }^{1 \#}$ \& Appolonius Shitiabai Kembu ${ }^{2}$ \\ ${ }^{1}$ Masters of Business Administration, Mount Kenya University, Kenya. \\ 'Lecturer, School of Business and Economics, Mount Kenya University, Kenya.
}

\#corresponding author

Type of Work: Peer Reviewed.

DOl: https://dx.doi.org/10.21013/jmss.v17.n2.p4

\section{How to cite this paper:}

Nang'oni, W.S., Kembu, A.S. (2021). Influence of Gender Diversity on Organization Performance at Kenya Urban Roads Authority. IRA-International Journal of Management \& Social Sciences (ISSN 24552267), 17(2), 46-55. DOI: https://dx.doi.org/10.21013/jmss.v17.n2.p4

(C) IRA Academico Research.

(c) Bry-No 4.0 International License subject to a proper citation to the publication source of the work.

Disclaimer: The scholarly papers as reviewed and published by IRA Academico Research are the views and opinions of their respective authors and are not the views or opinions of IRA Academico Research. IRA Academico Research disclaims any harm or loss caused due to the published content to any party.

IRA Academico Research is an institutional publisher member of Publishers International Linking Association Inc. (PILA-CrossRef), USA. IRA Academico Research is an institutional signatory to the Budapest Open Access Initiative. Hungary advocating the open access of scientific and scholarly knowledge. IRA Academico Research is a registered content provider under Open Access Initiative Protocol for Metadata Harvesting (OAI-PMH).

The journal is indexed \& included in WorldCat Discovery Service (USA), CrossRef Metadata Search (USA), WorldCat (USA), OCLC (USA), Open J-Gate (India), EZB (Germany) Scilit (Switzerland), Airiti (China), Bielefeld Academic Search Engine (BASE) of Bielefeld University, Germany, PKP Index of Simon Fraser University, Canada. 


\section{ABSTRACT}

Kenya's social-economic development blueprint as anchored by vision 2030 envisages growth in the public sector as the hub to its realization. The sector's infrastructure industry is to quadruple its contribution to GDP. In line with this concern, this study's investigation focused on the influence on the influence of gender diversity on organization performance at the Kenya Urban Roads Authority. The study was conducted at Kenya Urban Roads Authority Headquarters, in Nairobi and the target population was all categories of employees of KURA. The study adopted a descriptive research design. Stratified random sampling was used. The population of the study was 150 and the sample size was 30\% of the population which translated to 45 respondents. In order to collect data, structured questionnaires were issued to respondents. A pilot test was conducted to ascertain the validity and reliability of the questionnaire, a pretest and pilot survey was conducted. Statistical analysis was conducted using Statistical Package for Social Sciences (SPSS 24) to calculate descriptive analysis, reliability analysis, and correlation and regression analysis. The findings were presented using tables and figures. The correlation findings demonstrated weak but positive and significant effects of age and education diversity on organization performance. The effect of gender diversity on organizational performance was weak, positive but not significant. The multiple regression results showed that gender diversity accounts for up to $41.3 \%$ of the variation in organizational performance of KURA. As a result, the study recommends the HR department of KURA to enhance gender diversity in the organization through practices such as providing opportunities for growth and advancement for women, having a career development that includes women, structuring the training and development program to meet the criterial requirement of the male and female gender, involving women in the decision-making process as much as men and ensuring that employees are positive about gender diversity.

\section{Introduction}

Keywords: Gender, Diversity Management

As globalization increases in the world, there is a need for people to interact with those from diverse backgrounds in order to compete in the global framework. This challenge has now forced organizations to be more diverse in order to be competitive enough. As a result, focusing more on workforce diversity more so gender diversity is critical in ensuring that the workforce is competitive (Green, Lopez, Wysocki \& Kepner 2012).

The concept of workforce diversity is well documented in the USA and Europe. In the USA for instance, where racial and ethnic minorities are making upon the larger dominant white race, as well as women and people living with disabilities also seeking active employment, workforce diversity is well-grounded in organizations in the USA (Burns, Barton \& Kerby, 2012; Skaggs \& Ditomaso, 2014).

Tanova (2009) indicates that gender management differs from one organization to following as a result of the variations in each organization's culture, HRM policies, leadership vogue and internal values. Gender-focused policies and practices draw a job applicant's attention to an organization and increase their likelihood of accepting a job offer, leading to a gender-diverse workforce (Celani and Singh, 2011)

The National Cohesion and Integration Act, 2008 was also introduced in Kenya to ensure that there is no discrimination based on ethical backgrounds, racial or gender discrimination or based on nationality.

It appears that stereotypes and prejudices stay because of the main barriers in terms of gender diversity in organizations. Discrimination regarding gender, specifically unequal treatment of ladies, is specifically evident, that isn't even for any objective reasons (Wieczorek-Szyma'nska and Leo'nski 2017). Gender is one of the aspects of diversity in organizations, and gender diversity deals with the equal illustration of men and ladies within the geographical point. A work team could be a grouping inside which individuals ought to work conjointly to attain a synergic (Seroka-Stolka 2016). Understanding the factors of the variety in very work surroundings is crucial to underline the supply of people's behaviour and to foresee its impact on collective work. The problem is vital, as there are unit barriers for ladies within the marketplace. Within the Common Market, the development of women's presence on boards of administrators has been a gift since 2010, once the European Commission introduced the "Strategy for equality between girls and men 2010-2015". One among its targets was to possess forty per cent of ladies pictured in committees

\section{Problem Statement}

Kenya's social-economic development blueprint as anchored by vision 2030 envisages growth in the public sector as the key player to its realization. The Kenya Urban Roads Authority plays a key role in the infrastructure industry. 
According to a report by National Cohesion and Integration Commission, (NCIC) 2015, ethnicity in national government in Kenya have been extremely high during the past few years of the new 2010 constitution, and to maintain continuous success in the government, they must identify and analyze workforce diversity practices and develop strategies to meet them in order to adapt to the competition both globally and internationally.

Every organization should seek to ensure that they have better workforce diversity management (Alserhan, Forstenlechner \& Al-Nakeeb, 2010). There is an argument that the public sector needs to have ways of managing workforce diversity in order to compete. It should be an organizational culture (Anderson, 2012). If workforce diversity is appreciated and managed, it can improve competitive advantage, enhance organizational performance and productivity. Alserhan et al. (2010) argued that the organizations perceived to enhance workforce diversity normally attract and retain the best employees which improve their performance.

In the geographical region context like the Saudi context (Syed et al., 2018), and Egyptian context, organizations are still formed through social discrimination, cultural difference and majority-minority classifications (Bauer, 2011; unluckily and Mousa, 2016). Sadly, the Egyptian public health care sector doesn't totally secure justice and equal employment opportunities (Pande et al. 2017; Mousa, 2018). several studies have according to the in-out cluster differentiation, significant workloads, structure exclusion additionally to geographical point discrimination females face during this Egyptian sector (Pande et al. 2017). There have been challenges in the Kenyan Public Sector touching on Gender diversity, recruitment practices, training and deployment since issues of favouritism and ethnicity (Kipngok, 2013). While studies have linked workforce diversity to organizational performance, few studies have focused on the Kenyan context and specifically KURA hence a need for this study.

\section{The objective of the study}

This study sought to analyse the influence of Gender Diversity on organization performance at Kenya Urban Roads Authority.

\section{Value of the Research}

The current study intended to provide insights into knowledge about Gender Diversity on organization performance. The study will contribute towards filling the gap in the body of knowledge in the practices and operations of the Kenya Urban Roads Authority. The study intends to establish a link between Gender Diversity on organization performance, namely customer satisfaction. This should not only ensure that the public who put their hope on Kenya Urban Roads Authority for service delivery continue to reap the benefits.

\section{LITERATURE REVIEW}

\section{Theoretical Foundation of the research}

Social Identity Theory, the theory argues that social classes exist where people associate themselves with along the lines of gender, for instance, age cohort, religion etc (Tajfel \& Turner, 1985). There are two main functions for social classifications in the society, namely ordering others social environment which offers other people the means to define others. This leads to stereotypes after a person has already been assigned to a certain category (Hamilton, 1981).

\section{Empirical Literature Review}

\section{Gender Diversity and Organization Performance}

Connell (2012) defines gender as either a description of femininity or masculinity. Various studies have linked gender to performance. Powell (2011) indicated that gender is an inference of a person is either male or female. Gender diversity comes about when people perceive differences between themselves and others from the angle of gender. Most of the diversities come in form of prejudice or discrimination.

Emiki and Eunmi (2009) places more emphasis on managing gender diversity as compared t other diversities and argues that an organization cannot claim to have workforce diversity if gender diversity has not been well managed. According to Kossek, Lobel, and Brown (2005), the women workforce makes up54 per cent worldwide. Inmyxai and Takahashi (2010) on the other hand presented differences in organizational performance when comparing the male and female-headed organizations. It was established that diversified organizations performed better. 
It has been established in the recent interrogations that gender discrimination either through hiring, promotion or provision of services has no significance to the performance of the employees (Abbas and Hameed (2010). A study by Jerono (2012) and Zaman et al (2011) acknowledged that at the moment, there still exists gender discrimination among top-level management positions in the universities. The female felt that they were being discriminated against when it comes to promotions to top positions despite the fact that they have qualifications like their counterparts.

A study by Yukiko (2015) on the other hand indicated that among Japanese listed firms, gender diversity played a critical role in enhancing firm performance. After controlling for the size of the firm, gender and cultural diversity were the good determinants of better firm performance among these firms.

A study by Worthley et al. (2009) also agreed that the Japanese culture of hiring women has greatly improved in the recent past. Previously, their traditional approach demanded that men lead but in the contemporary modern world, women are taking managerial positions and that has seen the performance of the firms improve a great deal. The study, therefore, revealed that gender diversity was a critical determinant of firm performance.

\section{Conceptual Frame Work}

The conceptual model figure 1 presents a schematic picture of the researchers presumed perception of the existing relationship between the variables. The model suggests a relationship between gender diversity as the independent variable and organization performance as the dependent variable that may be influenced by gender diversity.

Fig 1. A Conceptual Model showing perceived Gender Diversity and Organization performance.

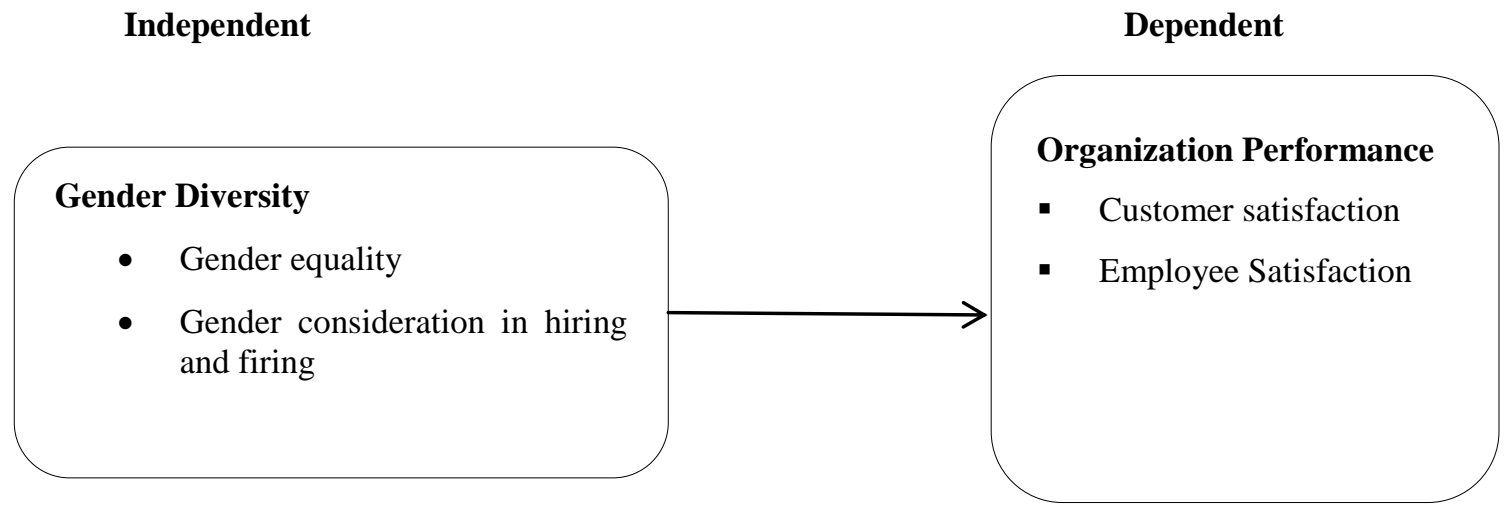

Source Researchers (2020)

The relationship indicated in Figure 1 was envisaged to exist in organizations, but the application of different Gender diversity tend to influence organizational performance. Gender diversity includes gender equality and gender considerations in hiring and firing to influence organizational performance.

\section{Methodology}

\section{Research Design}

The researcher used a descriptive research design. It is considered appropriate since the study was describing gender Diversity making generalized conclusions. It was also suitable for studies involving analysis of relationships as Kothari and Garg, (2016) notes, which this study was focused on.

\section{The population of the study}

The target population comprised of all the employees at KURA Head Quarters Nairobi Kenya. They are a total of 150 according to the human resource department 2021. 


\section{Sample Population}

According to Parten (2010), the sample size should be optimal whereby it must be sufficient, representative, reliable and flexible. For the purpose of this research, the sample size was 45 which is $30 \%$ of the target population of 150 employees from KURA. The researcher used a stratified sampling technique

\section{Data Collection}

A structured questionnaire was used to collect Primary data. According to Olatokun and Gbinedion, (2009), questioners are easy to administer and can be used for the gathering of information from any target group. The researchers sought authority from the National Council for Science, Technology and Innovation (NACOSTI) to collect data.

\section{Test of Validity and Reliability}

To ensure reliability and validity of the research instrument used in this study, a pilot study was conducted at the Kenya National Highways Authority on $10 \%$ of the sample size on a population that was not included in the main survey. The response was keyed into SPSS and then used to establish the reliability results by the use of Cronbach Alpha. The results presented in Table 1 indicated that the gender diversity used in the study had Cronbach Alpha values above 0.7 . The research tool was hence considered reliable and adequate for the main survey based on the reasoning by Robert (2016).

Table 1: Reliability Test Results

\begin{tabular}{|l|c|c|c|}
\hline Scale & Cronbach's Alpha & Number of Items & Comment \\
\hline Gender Diversity & 0.786 & 8 & Reliable \\
\hline Organizational Performance & 0.812 & 7 & Reliable \\
\hline
\end{tabular}

Source: Field Data (2021)

\section{Data Analysis and Interpretation}

Simple linear regression analysis was used to establish the nature and magnitude of the relationship between variables, and to test the hypothesized relationship. The coefficient $\mathbf{r}$ indicates the strength and direction of the linear relationship between variables of the study. The relationship is strong where $\mathbf{r}=0.5$ and above, moderately strong when $\mathbf{r}$ is between 0.3 and 0.49 , weak when $\mathbf{r}$ is below 0.29 , and a correlation of 0 indicates no relationship.

\section{Response Rate}

To achieve the objectives of the study, a total of 45 questionnaires were issued out to the Middle-Level Managers, Subordinate Staff and the Top Managers comprising of KURA at the Head Quarters in Nairobi Kenya. Out of the number, only one respondent failed to fill the questionnaire and thus the response rate was $98 \%$. The non-response rate was $2 \%$ and that approves the proclamation by Kothari and Garg (2016) that for a survey, the idyllic response rate is supposed to be above $50 \%$.

\section{Demographic Characteristics}

The respondent's demographic characteristics including the respondent's gender, work experience and level education in the Kenya Urban Roads Authority and their category was established and presented in Table 2.

Table 2 Respondent's Demographic Characteristics

\begin{tabular}{llcc}
\hline Demographic Characteristics & Category & Frequency & Percentage \\
\hline Gender & Male & 25 & 57 \\
& Female & 19 & 43 \\
Work Experience & Less than 2 Years & 9 & 20 \\
& 2 to 10 Years & 16 & 36 \\
& 11 to 20 Years & 15 & 34 \\
& More than 20 Years & 4 & 9 \\
\hline
\end{tabular}




\begin{tabular}{llcc}
\hline Level of Education & KCPE / KCSE & 6 & 14 \\
& Certificate / Diploma & 20 & 45 \\
& Degree & 18 & 41 \\
\hline
\end{tabular}

Source: Field Data (2021)

The results are presented in Table 2. It was confirmed that up to $57 \%$ of the employees of KURA are male while only $43 \%$ are female. However, this gender mix is acceptable in the Kenyan constitution which stresses that not more than a third of the employees in one organization should be of one gender.

The results also specified that up to $36 \%$ of the employees of KURA have work experience between 2 and 10 years, $34 \%$ have work experience between 11 and 20 years, while still a substantial number, 20\% have a work experience below 2 years and only $2 \%$ have worked in the organization for more than 20 years. In HR, the results imply that there is diversity in the work experience at KURA. It also implies that there is a high turnover rate past 20 years of work experience and similarly, it also shows that the organization engages in recruitment from time to time with the latest being within the last 2 years.

In regard to education level, it was posited that up to $45 \%$ of the employees of KURA have a Diploma or certificate as their highest level of education, $41 \%$ have a degree and higher while $14 \%$ have either a KCPE or KCSE certificate. This implies that there is diversity in the educational background of the employees and that the organization considers employees from varied educational backgrounds for varied tasks. Besides, it can be argued that the employees are literate.

\section{Descriptive Statistics}

Descriptive Findings of Gender Diversity.

The respondents rated five-point Likert scale questions on Gender Diversity and the findings are indicated in Table 3.

Table 3 Descriptive Findings of Gender Diversity

\begin{tabular}{lcc}
\hline Statement & $\begin{array}{c}\text { Standard } \\
\text { Deviation }\end{array}$ \\
\hline $\begin{array}{l}\text { While carrying out the process of hiring and recruiting employees the employer did not } \\
\text { discriminate based on gender. }\end{array}$ & 2.93 & 0.82 \\
$\begin{array}{l}\text { All employees are treated fairly irrespective of their gender. } \\
\text { Women at KURA never get the opportunities to work in cadres that allow them to use } \\
\text { their skills, training and education. }\end{array}$ & 3.02 & 0.88 \\
$\begin{array}{l}\text { KURA have opportunities that advance the growth of Women's career } \\
\text { KURA encourages career development that includes women }\end{array}$ & 3.02 & 0.79 \\
$\begin{array}{l}\text { The training and development programs at KURA are structured in such a way that it } \\
\text { meets the male and female requirements. }\end{array}$ & 4.61 & 0.49 \\
Women are involved in the decision-making process as much as men in KURA. & 4.59 & 0.51 \\
On gender diversity at KURA, am positive about it. & 4.55 & 0.50 \\
Average & 4.23 & 0.80 \\
\hline Source: Field Data (2021) & $\mathbf{3 . 9 3}$ & $\mathbf{0 . 6 6}$ \\
\hline
\end{tabular}

Source: Field Data (2021) 
The respondents rated statements on gender diversity on a scale of 1 to 5 as shown in Table 4.3. The results showed an agreement that opportunities for growth and advancement exist for women at KURA $(M=4.61)$, a career development that includes women is encouraged at KURA $(\mathrm{M}=4.50)$, KURA training and development program is structured to meet the criteria/ requirement of male and female gender $(\mathrm{M}=4.59)$, women are involved in the decision-making process as much as men in KURA $(\mathrm{M}=4.55)$ and that the employees are positive about gender diversity at KURA $(\mathrm{M}=4.23)$.

It was also established that the respondents neither agreed nor disagreed on whether they have been discriminated by employer while hiring and recruitment process on the gender basis $(M=2.93)$, fair treatment is given to all employees, whether they are male or female $(\mathrm{M}=3.02)$ and on whether at KURA, women are never given an opportunity to work in positions that utilize their skills, education and training $(\mathrm{M}=3.02)$. Averagely, there was an agreement that gender diversity strongly exists at KURA $(M=3.93)$. As indicated by the standard deviation, the responses were least varied $(\mathrm{SD}=0.66)$.

\section{Descriptive Findings of Organization Performance}

The respondents rated five-point Likert scale questions on Organization Performance and the findings are indicated in Table 4.

Table 4. Descriptive Findings of Organization Performance

\begin{tabular}{|c|c|c|}
\hline Statement & Mean & $\begin{array}{l}\text { Standard } \\
\text { Deviation }\end{array}$ \\
\hline KURA avails relevant training programs for its employees & 316 & 086 \\
\hline KURA avails client survey index on customer satisfaction & 5.10 & 0.00 \\
\hline $\begin{array}{l}\text { KURA allows high-quality operation and maintenance of physical infrastructure } \\
\text { for service delivery } \\
\text { Enhanced regulation of Service Providers/ agents is made by Kenya Urban Roads }\end{array}$ & 4.43 & 0.50 \\
\hline Authority periodically & 4.41 & 0.50 \\
\hline $\begin{array}{l}\text { The management style of the top managers of KURA is conducive for employees } \\
\text { to perform in all Directorates and Divisions. }\end{array}$ & 4.55 & 0.50 \\
\hline There are continuous phases of expansion of service coverage by KURA & 3.75 & 0.84 \\
\hline Commercialization of KURA services have led to high customer service & 3.30 & 1.00 \\
\hline KURA avails relevant training programs for its employees & 3.23 & 0.83 \\
\hline & 3.36 & 0.92 \\
\hline Average & $\mathbf{3 . 8 5}$ & 0.72 \\
\hline
\end{tabular}

Source: Field Data (2021)

The respondents rated statements on organization performance on a scale of 1 to 5 as shown in Table 4.6. The respondents agreed that KURA avails client survey index on customer satisfaction $(M=4.50)$, KURA allows highquality operation and maintenance of physical infrastructure for service delivery $(\mathrm{M}=4.43)$, enhanced regulation of Service Providers/ agents are made by Kenya Urban Roads Authority periodically $(\mathrm{M}=4.41)$, the management style of the top managers of KURA is conducive for employees to perform in all Directorates and Divisions $(\mathrm{M}=4.55)$ and that there are continuous phases of expansion of service coverage by KURA $(M=3.75)$.

The results also showed that the respondents neither agreed nor disagreed that KURA avails relevant training programs for its employees $(M=3.16)$, commercialization of KURA services have led to high customer service ( $M$ =3.30), KURA avails relevant training programs for its employees $(\mathrm{M}=3.23)$ and that KURA avails client survey 
index on customer satisfaction $(\mathrm{M}=3.36)$. On Average, there was an agreement that KURA performs well $(\mathrm{M}=$ $3.85)$ as also shown by the small variation in opinions $(\mathrm{SD}=0.72)$.

Table 5: Influence of Gender Diversity on Organization Performance

Model summary

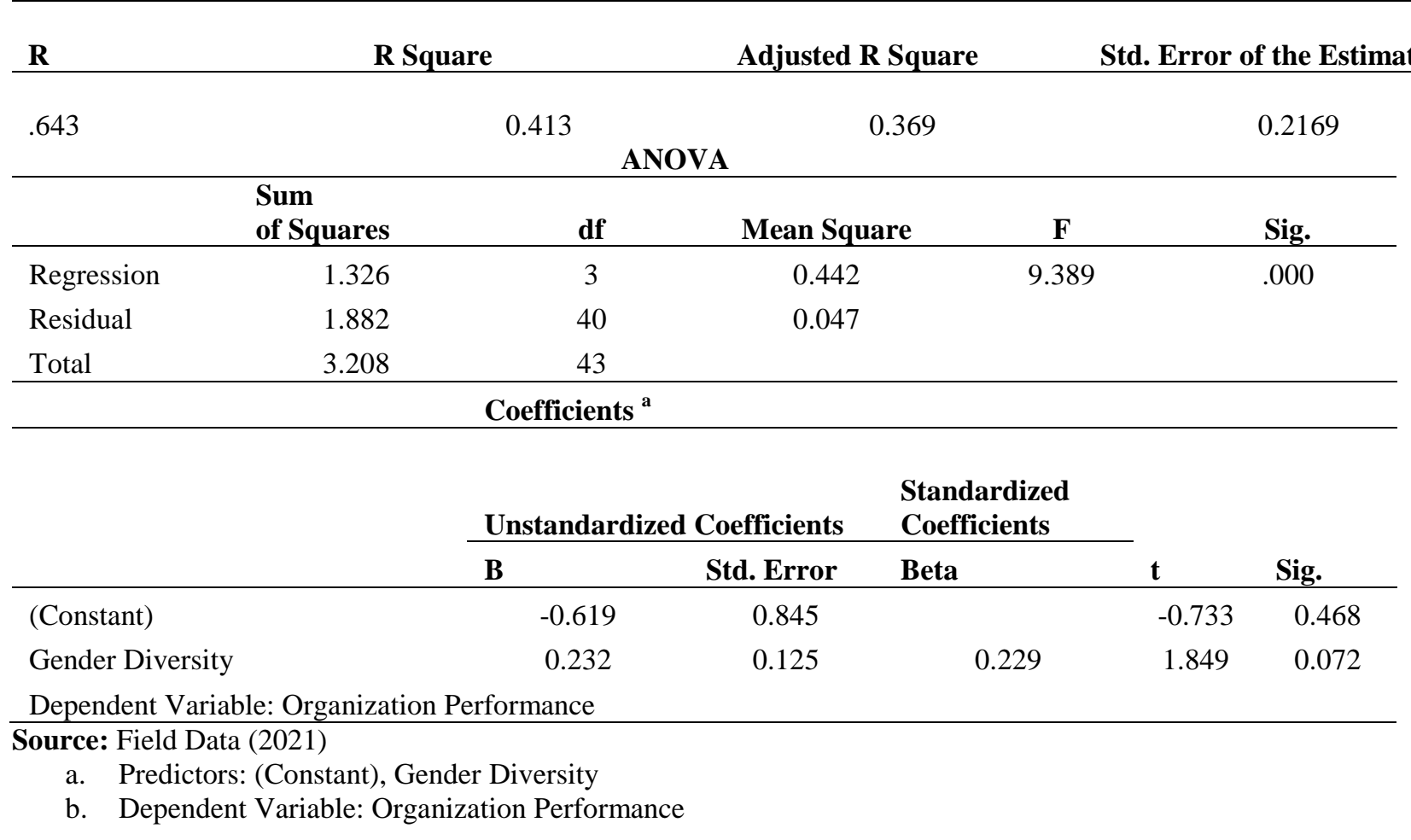

The results in Table 5 indicate a coefficient of determination is also called the R-square and it shows the percentage of the variation in the dependent variable accounted by the independent variable. The results indicate that the coefficient of determination (R Square) was 0.413 . This implies that gender diversity accounts for up to $41.3 \%$ of the variation in organizational performance of KURA.

The regression model fitness was also established. The ANOVA results are important in demonstrating whether the regression model established was a good fit. The results also indicate that the F statistic value of 9.389 was significant $(\mathrm{P}-\mathrm{Value}<0.05)$. This implies that the regression model linking Gender diversity to the organizational performance of KURA was a good fit.

The results also showed that gender diversity has a positive but not significant influence on the organizational performance of KURA $(\beta=0.232$; $\mathrm{P}$-value $>0.05)$. This was also the only insignificant form of gender diversity $(\mathrm{t}=$ 1.849). The findings imply that a unit increase in gender diversity would lead to an insignificant increase in the organizational performance of KURA by 0.232 units. The findings harmonize that of a study by Yukiko (2015) conducted among Japanese listed firms and discovered that gender diversity played a critical role in enhancing firm performance.

\section{CONCLUSION AND RECOMMENDATIONS Conclusion}

The study concludes that availability of gender diversity practices such as providing opportunities for growth and advancement for women at KURA, having a career development that includes women, structuring KURA training and development program to meet the criteria/ requirement of the male and female gender, involving women in the 
decision-making process as much as men in KURA and ensuring that employees are positive about gender diversity at KURA would improve organizational performance.

\section{Recommendation}

In regard to the findings that gender diversity has a positive influence on organizational performance, the study recommends the HR department of KURA to enhance gender diversity in the organization through practices such as providing opportunities for growth and advancement for women, having a career development that includes women, structuring the training and development program to meet the criteria/ requirement of the male and female gender, involving women in decision-making process as much as men and ensuring that employees are positive about gender diversity.

\section{ACKNOWLEDGEMENT}

The research was conducted under Research Permit NACOSTI/P/21/8615 that was issued by the National Council of Science, Technology and Innovation (NACOSTI) Nairobi, Kenya.

\section{REFERENCES}

[1]. Anderson (2012) The Impact of Social Media on Lodging Performance (Electronic article). Hospitality Report, 12(15), 6-11.

[2]. Alas, R. \& Mousa, M. (2016), "Cultural diversity and business schools' curricula: A case from Egypt", Problems and Perspectives in Management, Vol. 14 No.2, pp. 130-137. https://doi.org/10.21511/ppm.14(2-1).2016.01

[3]. Bauer, P. (2011), "The transition of Egypt in 2011: A new springtime for the European Neighbourhood Policy", Perspectives on European Politics and Society, Vol. 12 No.4, pp. 420-439. https://doi.org/10.1080/15705854.2011.622958

[4]. Bedi, Lakra \& Gupta, (2014) Workforce Diversity Management: Biggest Challenge Opportunity for 21st Century Organizations. Journal of Business and Management (Apr. 2014), PP 102-107. https://doi.org/10.9790/487X-1643102107

[5]. Burns, C., Barton, K., \& Kerby, S. (2012, July 12). The state of diversity in today's workforce. Retrieved from orce/ Buj

[6]. Celani A and Singh P (2011) Signaling theory and applicant attraction outcomes. Personnel Review 40: 222-238. https://doi.org/10.1108/00483481111106093

[7]. Darwin, J. R. \& Palanisamy, C. S. (2015). The Effects of Workforce Diversity on Employee Performance in Singapore Organizations. International Journal of Business Administration, Vol. 6, No. 2, pp. $17-29$. https://doi.org/10.5430/ijba.v6n2p17

[8]. Darwin, J. R. (2014). Age Diversity and Its Impact on Employee Performance in Singapore. International Journal of Research and Development in Technology \& Management Science - Kailash, Vol. 21, Is. 5, pp. $79-98$.

[9]. Elsaid (2012) the Effects of Cross Cultural Work Force Diversity on Employee Performance in Egyptian Pharmaceutical Organizations. vol 1 no 4 (2012) Feldman, (2009). Age, work experience, and the psychological contract. Journal of organization behavior November 2009. Pages 1053-1075. https://doi.org/10.5430/bmr.v1n4p162

[10]. European Commission. 2011. Strategy for Equality between Women and Men 2010-2015. Luxembourg: Publications O_ce of the European Union, Available online: https://eur-lex.europa.eu/legalcontent/ES/TXT/?uri=LEGISSUM\%3Aem0037 (accessed on 20 October 2020).

[11]. Feldman, (2009). Age, work experience, and the psychological contract. Journal of organization behavior November 2009. Pages 1053-1075. https://doi.org/10.1002/job.599

[12]. Fernandez (2013) Effects of an emotional intelligence intervention on aggression and empathy among adolescents. Epub Jul 31.2013 Oct; 36(5):883-92. https://doi.org/10.1016/j.adolescence.2013.07.001

[13]. Gellner and Veen,( 2009) The Impact of Aging and Age Diversity on Company Performance Prof. Dr. Uschi Backes-Gellner, University of Zurich1 Stephan Veen, University of Zurich

[14]. Gizawi, (2014). The Dynamic Capabilities Theory: Assessment and Evaluation as a Contributing Theory for Supply Chain Management.3 Jul 2014 - Author: Nabil El Gizawi ... 2013, p. 522)

[15]. Green, K.A, López, M, Wysocki, A and Kepner, K. (2008) Diversity in the Workplace: Benefits, Challenges, and the Required Managerial Tools. Institute of Food and Agricultural services, University of Florida

[16]. Gupta, C.B. (2011) Human resource management, Sultan Chand \& Sons Educational Publishers, New Delhi Imran, Muhammad. 2009. Public Transport in Pakistan: A Critical Overview. Journal of Public. vol 12 (2009) no 2. https://doi.org/10.5038/2375-0901.12.2.4

[17]. Gupta, R. (2013). Workforce Diversity and Organizational Performance. International Journal of Business and Management Innovation, Vol. 2, Is. 6, pp. 36 - 41. 
[18]. Imran, Muhammad. 2009. Public Transport in Pakistan: A Critical Overview. Journal of Public Transportation, 12 (2): 53-83. https://doi.org/10.5038/2375-0901.12.2.4

[19]. JChandaa ,D’Nettob and Monga(2009). The International Journal of Human Resource Management, Vol. 20 , No. 2, February 2009, 235-251. https://doi.org/10.1080/09585190802670516

[20]. Kothari (September 2016), Research Design. Research in Social Science: Interdisciplinary Perspectives, Edition: 1st, Chapter: Research Design, pp.17

[21]. Kumar, A. (2011). Research and Writing Skills. New York, NY: Lulu Press. (978-1-4466-0560-8)

[22]. Muriungi \& Kepha, International. journal. business. management \& entrepreneur 2(1): 15 - 28, April 2018 Emiko and Eunmi (2009).Workforce Diversity: A Key to Improve Productivity 2014, Pages 76-85

[23]. Mwatumwa (2016) Int Journal of Business Management and Entrepreneurship 2(1): 15 - 28, April 2018

[24]. Myxai and Takahashi (2010). "Market orientation and performance: the contingency role of external environment" "Environmental Economics" Journal. 7(2), 130-137. https://doi.org/10.21511/ee.07(2).2016.14

[25]. Olatokun and Gbinedion, (2009), Use of questionnaires for acquiring information on public perception of natural. Hazards Nat. Hazards Earth Syst. Sci., 9, 1307-1325, 2009. https://doi.org/10.5194/nhess-9-1307-2009

[26]. Pande, A. El Shalakani, A. \& Hamed, A. (2017), "How can we measure progress on social justice in health care? The case of Egypt", Health Systems \& Reform, Vol. 3 No. 1, pp. 14-25, https://doi.org/10.1080/23288604.2016.1272981

[27]. Ruhl (2014) Designing Administrative Law for Adaptive Management Journal.Vol 67 Pg 1-87

[28]. Seroka-Stolka, Oksana. 2016. Zespoły pracownicze w ewolucji zarza dzania s'rodowiskowego

[29]. przedsie, biorstw - analiza empiryczna. Przegla d Organizacji 2: 60-67.

[30]. Skaggs and Ditomaso (2014) Effect of workforce diversity on performance. International Academic Journal of Human Resource and Business Administration. Volume 3, Issue 1, pp.150-169.

[31]. Syed, J., Ali, F. \& Hennekam, S.(2018), "Gender equality in employment in Saudi Arabia: a relational perspective”, Career Development International, Vol. 23 No. 2, pp. 163-177. https://doi.org/10.1108/CDI-072017-0126

[32]. Tanova, C. (2009), The Impact of National Culture, Eastern Mediterranean University, Cyprus.

[33]. Tajfel and Turner (2006).Psychology of Entertainment, Publisher: NY: Lawrence Erlbaum Associates, Editors: J. Bryant, P. Vorderer, pp.255-272

[34]. The constitution of Kenya (2010) National Council for Law Reporting, With the Authority of Attorney General

[35]. The National Gender and Equality Commission Act (2011) National Council for Law Reporting, With the Authority of Attorney-General

[36]. Wieczorek-Szyma' nska, Anna, andWojciech Leo’ nski. 2017. Gender Diversity in Polish Enterprises. Social, Economic and Law Research 4: 186-200. https://doi.org/10.21684/2411-7897-2018-4-1-186-200

[37]. Wong and Wong, Prajogo, (2007).International Journal of Research Science \& Management Vol 3(3): March 2016. 